Volume 14. Nomor 1. June 2019 Page 25-33
Pandecta
http://journal.unnes.ac.id/nju/index.php/pandecta

\title{
Tanggung Jawab Negara terhadap Penembakan Pesawat MH17 berdasarkan Hukum Internasional
}

\author{
Dewa Gede Sudika Mangku, I Ketut Radiasta
}

Universitas Pendidikan Ganesha Singaraja, Indonesia

DOI: http://dx.doi.org/10.15294/pandecta.v14i1.18987

\begin{abstract}
Article info
\section{Abstrak}

Article History:

Received : January 2019

Penelitian ini bertujuan untuk mengetahui dan menganalisis bentuk pertanggung Accepted: June 2019

Published: June 2019 jawaban Negara Ukraina dalam penembakan pesawat MH17 Malaysia Air Lines. Jenis penelitian yang digunakan adalah jenis penelitian hukum normatif, Jenis penelitian yang digunakan adalah jenis penelitian hukum normatif, maka pendekatan

Keywords:

Malaysia Air Lines MH17,

attact, accountability;

international civil aviation dalam penelitian ini adalah pendekatan undang- undang (statute approach), pendekatan kasus (case approach), dan pendekatan sejarah (historical approach), sumber bahan hukum yang digunakan yaitu bahan hukum primer, sekunder, dan tersier. Teknik pengumpulan bahan hukum yang digunakan dengan teknik studi dokumen dan bahan hukum tersebut dilakukan evaluasi, interpretasi, argumentasi dan dibahas secara deskriptif. Hasil penelitian menunjukkan Tanggung jawab negara Ukraina terhadap Penembakan Pesawat malaysia Air Lines MH17 bahwa Negara Ukraina harus bertanggung jawab untuk memberikan pelayanan keselamatan dan keamanan atas kedaulatan ruang udara di atas wilayahnya yang dilewati oleh pesawat Malaysia Air Lines $\mathrm{MH} 17$ berupa pelayanan navigasi penerbangan, Setiap negara diharapkan selalu melakukan pengawasan terhadap ruang udara yang menjadi kedaulatan wilayah udara di atas yang menjadi jalur rute penerbangan sipil internasional serta melakukan koordinasi dengan baik terhadap ICAO (International Civil Aviation Organozation) untuk menjaga keamanan penerbangan sipil internasional.
\end{abstract}

\begin{abstract}
The purpose this research were to find out and analyze the form of the State of Ukraina accountability in shooting MH17 Malaysia Air Lines aircraft. The type of research used is a type of normative legal research, the approach in this study is the law approach, case approach, and historical approach, the sources of legal material used are primary, secondary and tertiary legal materials. Legal material collection techniques used with document study techniques and legal materials are evaluated, interpreted, argued and discussed descriptively. The results of the study show the responsibility of the Ukraina for Malaysia Air Lines MH17 Aircraft Shooting that the State of Ukraina must be responsible for providing safety and security services for the sovereignty of the air space over its territory by Malaysia Air Lines MH17 in the form of flight navigation services. Every country is expected to always supervise the airspace which is the sovereignty of the airspace above which becomes the international civil aviation route and to coordinate well with the ICAO (International Civil Aviation Organozation) to maintain the security of international civil aviation.
\end{abstract}




\section{Pendahuluan}

Transportasi merupakan kebutuhan setiap manusia dalam melakukan aktivitas untuk memenuhi kehidupan baik transportasi lokal, nasional, dan internasional. Salah satu bagian dari sistem transportasi yaitu penerbangan yang memiliki karakter tersendiri yaitu menggunakan teknologi yang canggih, mampu bergerak dalam waktu yang begitu cepat, memiliki manajemen pelayanan yang handal, serta memerlukan jaminan dan keselamatan yang optimal.

Semakin diiringi dengan berkembangnya ilmu pengetahuan dan teknologi yang semakin mendukung dalam dunia penerbangan telah mampu dalam meningkatkan kualitas pelayanan dan meningkatkan alatalat penerbangan yang cukup canggih dan beragam. Kemajuan teknologi dalam penerbangan tentunya berdampak positif terhadap keselamatan penerbangan. Pemenuhan keselamatan penumpang dalam penerbangan merupakan sesuatu yang mutlak dan harus terpenuhi untuk meningkatkan taraf hidup manusia (Nainggolan, 2014:4).

Penyelenggaraan penerbangan sipil baik penerbangan nasional maupun penerbangan internasional tentunya harus mengacu kepada ketentuan-ketentuan hukum nasional maupun ketentuan hukum internasional yang berlaku, hal ini dimaksud untuk tetap menjamin hak-hak penumpang, menjamin keselamatan penumpang, awak pesawat udara, dan pesawat udara itu sendiri serta barang-barang yang diangkut (Nainggolan, 2014:4).

Pengaturan mengenai penyelenggaran penerbangan sipil internasional telah diatur dalam berbagai Konvensi-Konvensi internasional. Dalam hukum udara internasional publik terdapat Konvensi Chicago tahun 1944 Tentang Unifikasi Beberapa Ketentuan Pengangkutan Udara Internasional yang merupakan konstitusi penerbangan sipil internasional. Konvensi tersebut dijadikan sebagai tolak ukur dalam pembuatan hukum nasional bagi negara anggota Organisasi Penerbangan Sipil Internasional (International Civil Aviation Organization) (Wahdah, 2015:12).

Unifikasi hukum mengenai pener- bangan sangat penting dalam penerbanganpenerbangan internasional, hal ini dikarenakan dalam penerbangan-penerbangan internasional akan melewati beberapa wilayah negara asing yang memiliki yurisdiksi maupun tidak memiliki yurisdiksi, kemudian penumpang didalam pesawat juga memiliki kewarganegaraan yang beragam, sehingga dengan dilakukannya unifikasi hukum mengenai penerbangan sipil apabila sewaktuwaktu terjadi permasalahan seperti kejadian penembakan pesawat udara sipil antar lain kita dapat lihat kejadian jatuhnya maskapai penerbangan Malaysia Air Lines MH17.

Pada tanggal 17 juli 2014 yang lalu telah terjadi sebuah tragedi menyedihkan yang menimpa pesawat penumpang milik Malaysia Air Lines dengan kode penerbangan $\mathrm{MH} 17$ dengan rute penerbangan Amsterdam- Kuala Lumpur. Pesawat ini ketika melewati wilayah udara Ukraina tepatnya di dekat perbatasan Ukraina dan Rusia yang sedang terjadi konflik militer di tembak jatuh dan yang paling mengenaskan adalah seleuruh penumpang yang berjumblah 283 dan 15 kru pesawat tidak ada satupun yang selamat (Wahdah, 2015:2). Pesawat boeing 777200ER ini dikabarkan jatuh 50-80 kilometer (31-50 mil) sebelum memasuki ruang udara Rusia (Manihuruk, 2016:2).

Pesawat Malaysia Air Lines MH17 ditembak saat melintasi wilayah perbatasan Ukraina dan Rusia yang merupakan daerah rawan konflik antara Pemerintah Ukraina dan Pemberontak Pro-Rusia (Manihuruk, 2016:3). Pemerintah Ukraina juga menyatakan berdasarkan rekaman kotak hitam dari pesawat Malaysia Air Lines MH17 menunjukkan bahwa pesawat itu jatuh oleh serpihan dari rudal yang ditembakkan. Klaim itu disampaikan setelah inspektur internasional termasuk dari Polisi Federal Australia, berhasil mencapai lokasi tragedi jatuhnya MH17. Para penyelidik itu berhasil menjangkau lokasi tragedi MH17 meski berada di tengah pertempuran sengit di daerah yang dikuasai separatis Pro-Rusia di kota Donetsk Ukraina Timur. Data dari kotak hitam pesawat Malaysia Air Lines MH17 dibongkar di Inggris, setelah pejabat Malaysia menyerahkan kepada 
penyelidik internasional (Prasetyani, 2014:2$3)$.

Tragedi jatuhnya pesawat Malaysia Air Lines MH17 banyak memakan korban yang memiliki kewarganegaraan yang berbeda. Hampir sebagaian besar penumpang Malaysia Air Lines MH17 yang jatuh di Ukraina berkebangsaan Belanda, tercatat 192 orang Belanda turut menjadi korban, Negara lain yang warganegaranya turut menjadi korban jatuhnnya pesawat Malaysia Air Lines MH17 yaitu Malaysia, Australia, Indonesia, United Kingdom, Belgium, Jerman, Filipina, Kanada, New Zeland, Vietnam, Hongkong, Irlandia, Afrika Selatan, United States. Seluruh negara yang ikut menjadi korban meminta untuk dilakukan investigasi dan pertanggung jawaban dari pihak yang terlibat dalam insiden tersebut (Putri, 2015:1).

Pada Pasal 1 Konvensi Chicago 1944 Tentang Penerbangan sipil internasional mengakui bahwa setiap Negara berdaulat mempunyai kedaulatan yang utuh dan penuh atas ruang udara diatasnya (Martono,2016:69). Ketentuan ini merupakan salah satu tiang pokok hukum internasional yang mengatur ruang udara (Rudy, 2011:32). Negara yang wilayah kedaulatannya berada dibawah suatu ruang udara tertentu yang disebut sebagai negara kolong dimana memiliki kedaulatan sampai ketinggian tidak terbatas dan hanya dibatasi oleh kewajiban untuk memberikan hak lintas damai kepada pesawat udara negara lain (Rudy, 2011:33).

Negara sebagai subjek hukum internasional dapat dimintakan tanggung jawab ketika suatu negara tidak melaksanakan kewajiban, telah melakukan tindakan-tindakan kelalaian yang melawan hukum (Sefriani, 2016:253). Negara berkewajiban untuk tidak menyalah gunakan kedaulatan itu sendiri, ketika suatu negara menyalah gunakan kedaulatannya, maka negara tersebut dapat diminta suatu pertanggungjawaban atas tindakan dan kelalaiannya (Adolf, 1991:174).

Negara Ukraina telah melakukan kelalaian terhadap kadaulatan ruang udara yang ada diatas wilayah kedaulatannya yang dilalui oleh pesawat Malaysia Air Lines yakni tidak melakukan koordinasi terkait penetapan zonal larangan terbang kepada ICAO (International Civil Aviation Organization) dan IATA (Air Transport Center), sehingga (ICAO) Organisasi Internasional Penerbangan Sipil mengklaim rute yang dilalui pesawat $\mathrm{MH} 17$ adalah rute aman. Asosiasi Transportasi Udara internasional (IATA) juga menyatakan jalur penerbangan yang dilalui oleh MH17 tidak termasuk jalur terlarang (Kompas.com, 2014, diakses pada 22 April 2019).

Peristiwa terjadinya kecelakaan pesawat Malaysia Air Lines bukan hanya semata menjadi tanggung jawab Negara Ukraina semata, namun mengingat banyak penumpang yang menjadi korban dalam insiden tersebut sudah dipandang perlu pihak maskapai penerbangan ikut serta dalam memberikan tanggung jawab khususnya terhadap penumpang. Dalam doktrin hukum iternasional dikenal mengenai pemindahan resiko dari pelaku kepada korban, dalam hal ini kerugian yang di derita oleh korban pesawat Malaysia Air Lines MH17 ditanggung oleh pihak perusahaan maskapai penerbangan yang menyediakan transportasi tersebut yaitu Malaysia Air Lines. Mengenai ganti rugi terhadap para korban penumpang yang meninggal dan atau terluka (bodily injury) diatur dalam Konvensi Montreal 1999 Tentang Tentang Unifikasi Beberapa Ketentuan Pengangkutan Udara Internasional. Segala kejadian yang dapat menimbulkan kerugian bagi orang lain baik itu disebabkan oleh kesalahan pihak maskapai maupun disebabkan oleh teroris atau pihak ketiga bisa menuntut klaim ganti rugi terhadap perusahaan angkutan udara (Wahdah, 2015:4-6).

Berdasarkan uraian diatas nampak terlihat hal-hal yang sangat penting untuk dibahas lebih lanjut mengenai bentuk pertanggung jawaban negara Ukraina selaku negara yang berdaulat terhadap ruang udara, serta bentuk ganti rugi yang diberikan maskapai penerbangan terhadap penumpang. Sehingga penulis tertarik untuk membuat penulisan hukum yang berjudul "Tanggung Jawab Negara Terhadap Penembakan Pesawat MH17 Diatas Wilayah Konflik Bersenjata Antara Ukraina Dan Rusia Berdasarkan Hukum Internasional". 


\section{Metode Penelitian}

Jenis penelitian yang digunakan penulis dalam penelitian ini adalah jenis penelitian hukum normatif. Menurut Soerjono Soekanto dan Sri Mamudji mendefinisikan penelitian hukum normatif adalah penelitian hukum yang dilakukan dengan cara meneliti bahan pustaka dan dokumen peraturan perundangundangan (Ishaq, 2017:66). Jenis penelitian yang digunakan adalah jenis penelitian hukum normatif, maka pendekatan dalam penelitian ini adalah pendekatan undangundang (statute approach), pendekatan kasus (case approach), dan pendekatan sejarah (historical approach), sumber bahan hukum yang digunakan yaitu bahan hukum primer, sekunder, dan tersier. Teknik pengumpulan bahan hukum yang digunakan dengan teknik studi dokumen dan bahan hukum tersebut dilakukan evaluasi, interpretasi, argumentasi dan dibahas secara deskriptif.

\section{Hasil Penelitian dan Pembahasan}

\section{Istilah dan Definisi Pertanggungjawaban Negara}

Ada tiga istilah hukum yang sering digunakan untuk menyebut kata tanggung jawab menurut Peter Salim. Istilah-istilah yang dimaksud adalah Accountability, Liability, dan Responsibility. Demikian halnya menurut Henry Campbell Black dalam Blak's law Dictionary-nya. Istilah pertama, accountability pada umumnya dikaitkan dengan masalah keuangan atau pembukuan ataupun juga dapat digunakan terkait masalah suatu kepercayaan terhadap lembaga tertentu yang berkaitan dengan keuangan (Sefriani, 2016:251-252).

Istilah kedua, adalah liability yang merupakan pertanggung jawaban hukum. Tanggung jawab dalam makna liability, berarti tanggung jawab dalam ranah hukum, dan biasanya diwujudkan dalam bentuk tanggung jawab keperdataan, kewajiban membayar ganti kerugian yang diderita. Pada umumnnya liability dikaitkan dengan gugatan di depan pengadilan perdata. Menurut kamus besar bahasa indonesia tanggung jawab (liability) dapat pula berarti menangung segala sesuatu kerugian yang terjadi akibat perbuatannya atau perbuatan orang lain yang bertin- dak untuk dan atas namanya. Dalam hukum keperdataan, prinsip-prinsip tanggung jawab dapat dibedakan sebagai berikut: (Sefriani, 2016:252)

1. Prinsip tanggung jawab berdasarkan adanya unsur kesalahan (liability based of fault)

2. Prinsip tanggung jawab berdasarkan praduga (presumption of liability)

3. Prinsip tanggung jawab mutlak (absolute liability or strict liability)

Istilah ketiga yaitu responsibility, dalam bahasa ingris "responsibility berasal dari kata "response" yang berarti tindakan untuk merespon suatu masalah atau isu, dan ability yang berarti kemampuan. Maknanya, responsibility merupakan tindakan yang bersifat suka rela, karena response yang dilakukan disesuaikan dengan ability yang bersangkutan. Responsibility sering diartikan dengan "ikut memikul beban" akibat dari suatu perbuatan. Menurut kamus besar bahasa indonesia, tanggung jawab (responsibility) dapat diartikan sebagai wajib menanggung segala sesuatunya atau terjadi sesuatu dengan dipersalahkan, dituntut, diancam hukuman pidana, menerima beban akibat tindakan sendiri atau orang lain. Dengan demikian, dapat dikatakan bahwa perbedaan antara tanggung jawab dalam makna responsibility dengan tanggung jawab dalam makna liability pada hakikatnya hanya terletak pada sumber pengaturannya (Sefriani, 2016:252-253).

Tanggung jawab negara (state responsibility) merupakan prinsip fundamental dalam hukum internasional yang bersumber dari doktrin para ahli hukum internasional. Tanggung jawab negara timbul bila terdapat pelanggaran atas suatu kewajiban internasional untuk berbuat sesuatu, baik kewajiban tersebut berdasarkan perjanjian internasional maupun berdasarkan pada kebiasaan internasional (Sujatmoko, 2016:28).

Pengertian tanggung jawab negara jika merujuk pada Dictionary of Law adalah: "Obligation of a state to make reparation arising from a failure to comply with a legal obligation under international law" (Martin, 2002:477). Dari rumusan tersebut tanggung jawab negara dapat diartikan sebagai kewaji- 
ban untuk melakukan perbaikan (reparation) yang timbul ketika suatu negara melakukan kesalahan untuk mematuhi kewajiban hukum berdasarkan hukum internasional. Sedangkan dalam Black's Law Dictionary hanya terdapat pengertian tanggung jawab secara sempit yaitu answerability or accountability.

Sugeng Istanto memberikan pengertian terhadap tanggung jawab negara dengan menggunakan istilah pertanggungjawaban negara. Menurutnya pertanggungjawaban negara adalah kewajiban negara memberikan jawaban yang merupakan perhitungan atas suatu hal yang terjadi dan kewajiban untuk memberikan pemulihan atas kerugian yang mungkin ditimbulkan (Istanto, 2004:105).

Di samping itu tanggung jawab negara (state responsibility) muncul sebagai akibat dari adanya prinsip persamaan dan kedaulatan negara (equality and sovereignty of state) yang terdapat dalam hukum internasional. Prinsip ini kemudian memberikan kewenangan bagi suatu negara yang terlanggar haknya untuk menuntut suatu hak yaitu berupa perbaikan (reparation) (Hingorani, 1984:241). Meskipun suatu negara mempunyai kedaulatan atas dirinya, tidak lantas negara tersebut dapat menggunakan kedaulatannya tanpa menghormati kedaulatan negara-negara lain. Hukum internasional telah mengatur bahwa kedaulatan tersebut berkaitan dengan kewajiban untuk tidak menyalahgunakan kedaulatan itu sendiri, karena apabila suatu Negara menyalahgunakan kedaulatannya, maka negara tersebut dapat dimintai suatu pertanggungjawaban atas tindakan dan kelalaiannya (Adolf, 1991:174).

\section{Bentuk-Bentuk Pertanggungjawaban Negara.}

Terdapat beberapa bentuk pertanggungjawaban yang diakui dalam hukum internasional. Salah satunya adalah reparation. Akan tetapi, pada saat ini reparation sudah jarang digunakan karena pada saat ini lebih sering persoalan mengenai ekspropiasi yang lebih bersipat politis. Di samping itu, penggunaan istilah ini makin mebingungkan ketika Brownline menerapkan istilah reparation untuk ditujukan kepada semua tindakan yang diambil oleh negara yang terkena pertang- gungjawaban seperti: pembayaran kompensasi atau restitusi, sebuah apologi, penghukuman atas individu yang bertanggungjawab, mengambil tindakan supaya tidak terjadi pengulangan, segala bentuk pembalasan (statisfaction) lainnya.

Brownline membuat perbedaan antara restitusi dan konpensasi. Kompensasi adalah reparasi dalam pengertian sempit yang berhubungan dengan pembayaran sejumblah uang sebagai ganti atas kerugian (Thontowi, 2006:204).

Kompensasi dapat diberikan terhadap pelanggaran-pelanggaran oleh suatu Negara walaupun pelanggaran tersebut tidak berhubungan dengan kerugian yang bersifat finansial, seperti pelanggaran terhadap kekebalan diplomatik atau konsuler yang hanya gati rugi sebagai reparasi moral atau politis. Akan tetapi, prinsip dasar dalam pertanggungjawaban atas kesalahan yang dilakukan oleh suatu negara merupakan sebuah persoalan yang dapat kita generalisir (Thontowi, 2006:204).

Semua bentuk retribusi harus memiliki tujuan utama yaitu perlindungan kepentingan negara penuntut yang harus dibedakan dengan model yang hanya ditujukan untuk mendapatkan legal standi untuk melindungi kepentingan hukum yang tidak identik dengan negara yang bersangkutan ataupun negara-negara lain. Sehingga sebisa mungkin restitusi tersebut dapat mengembalikan situasi ketika tidak terjadinya pelanggaran (Thontowi, 2006:205).

Tanggungjawab negara berkaitan dengan keselamatan dalam penerbangan, di bidang keselamatan dan keamanan penerbangan sipil, Pasal 12 Konvensi Chicago 1944; negara berdasarkan ketentuan itu bertanggung jawab atas pelayanan semua pesawat yang melintas di atas wilayahnya karena setiap penerbangan membutuhkan panduan dari darat oleh petugas air traffic controller (ATC). Negara yang dilintasi suatu pesawat wajib memberikan layanan panduan penerbangan. Layanan panduan berfungsi sebagai pelaksanaan penerbangan yang selamat dan aman, di samping layanan selama di darat seperti bandara dan informasi cuaca. Pemberian layanan yang dilengkapi fasilitas yang 
baik mutlak dibutuhkan. Pasal 28 Konvensi Chicago 1944 mengamanahkan negara anggota peserta konvensi ini wajib memberi pelayanan yang baik melalui fasilitas yang sesuai standar internasional.

\section{Pertanggung Jawaban Negara Ukraina Dalam Penembakan Pesawat Malaysia Air Lines $\mathrm{MH} 17$}

Insiden penembakan pesawat Malaysia Air Lines MH17 di wilayah udara Ukraina berdasarkan Kronologi kasus diatas dapat dikatakan bahwa penembakan tersebut terjadi karena tidak ditutupnya rute penerbangan yang melewati wilayah perbatasan Ukraina dan Rusia, di kota Donetz, desa Grabovo yang dikuasai oleh gerakan separatis pro-Rusia yang dianggap memiliki potensi ancaman konflik bersenjata.

Zona larangan terbang diatur dalam Pasal 9 Konvensi Chicago 1944 tentang penerbangan sipil internasional, mengenai zona larangan teebang mengatur sebagai berikut:

a. Each contracting state may, for reason of military necessity or public safety, restrict or prohibit uniformly the aircraft of other states from flying over certain areas of its teritory, provided that no distinction in this respect is mae between the aircraft of the state whose territory is involved, engaged in international scheduled airlines service, and the aircraft of the other contracting states likewise engaged. Such prohibited area shall reasonable extent and location so as not to interference unnecessarily with navigation. Description of such prohibited areas in the territory of contracting states, as while as any subsequent alteration therein shall be communicated as soon as possible to the other contracting states and to international civil aviation organization.

b. Each contracting states reserves also the right, in exceptional circumtanses or during a period of emergency, or in the interest of public safety, and with immediate effect, temporary to restrict or prohibit flying over the wholeor any part in its territory, on condition that such ristriction or prohibition shall be applicable without distinction of nationality to aircraft of all other states.

c. Each contracting states, under such regulation as it may prescribe, may require any aircraft entering the areas contemplated in the subparagraph (a) or (b) above to effect a landing as soon as praticable there after at some designated airport within its territory.

Pesawat udara nasional maupun asing dilarang terbang di atas daerah terlarang (prohibited area) atau daerah terbatas (restricted area) untuk menjamin keselamtan penerbangan (aviation safety), ekonomi nasional (national prosperity), maupun kemanan nasional (national security). Larangan tersebut berlaku umum tehadap pesawat udara manapun juga, tidak boleh diskriminasi. Bila pesawat udara asing dilarang terbang didaerah tersebut, pesawat udara nasional juga harus dilarang. Penentuan daerah terlarang hanya didasari atas pertimbangan keselamatan nasional (national security), keselamatan penerbangan (aviation safety), mapun kemakmuran nasional (national prosperity). Tidak diperbolehkan penentuan daerah terlarang atas pertimbangan politik (Nainggolan, 2014:16).

Menurut ICAO (International Civil Aviation Organization) yang merupakan badan pengatur penerbangan sipil internasional, melakukan distribusi dan melakukan pemantauan serta evaluasi terhadap penerapan penerbangan sipil telah mengklaim rute yang dilalui pesawat Malaysia Air Lines MH17 adalah rute aman. IATA (Asosiasi Transportasi Udara Internasional) juga menyatakan bahwa jalur yang dilalui penerbangan pesawat Malaysia Air Lines MH17 tidak termasuk daerah terlarang. Sehingga tidak ada alasan bahwa terjadi kelalaian ICAO (International Civil Aviation Organization) terhadap rute penerbangan yang dilalui oleh pesawat Malaysia Air Lines MH17. Rute yang dilewati oleh pesawat Malaysia Air Lines MH17 merupakan rute yang dilewat selama bertahun-tahun oleh Malaysia Air Lines maupun maskapai penerbangan lainnya (Merdeka.com. 2014. diakses 12 April 2019). 
Berdasarkan teori kepemilikan ruang udara (The Air Sovereignty theory) menyatakan bahwa udara itu tidak bebas, sehingga negara berdaulat atas ruang udara ang ada diatas wilayah negaranya. Teori ini mengkelompokkan kedaulatan terhadap ruang udara yang berada di atas wilayah negarannya menjadi: (1) Negara kolong berdaulat penuh hanya terhadap satu ketinggian tertentu di ruang udara; (2) Negara kolong berdaulat penuh, tetapi dibatasi oleh hak lintas damai bagi navigasi pesawat-pesawat udara asing; (3) Negara kolong berdaulat penuh tanpa batas (Scribd.com, 2018. diakses pada 15 April 2019). Pasal 1 Konvensi Chicago 1944 tentang penerbangan sipil internasional juga menyatakan bahwa setiap negara berdaulat mempunyai kedaulatan yang utuh dan penuh atas ruang udara di atas wilayahnya. Dari Pasal tersebut memberikan pandangan bahwa perwujudan dari kedaulatan yang penuh dan utuh atas ruang udara di atas wilayah teritorialnya adalah: (1) Setiap negara berhak mengelola dan mengendalikan secara penuh dan utuh atas ruang udara nasionalnya; (2) Tidak satupun kegiatan atau usaha di ruang udara nasionalnya tanpa mendapatkan izin terlebih dahulu atau sebagaimana telah diatur dala suatu perjanjian udara antara negara dengan negara lain baik bilateral maupun mulrilateral (Coursehero.com, 2018, diakses pada 15 April 2019).

Berdasarkan hal tersebut diatas maka dapat dikatakan bahwa negara berdaulat penuh atas wilayah udaranya, sehingga setiap pengangkut komersial yang melintasi wilayah udaranya dapat terjamin keselamatan dan keamanan penerbangan yang dilakukan. Melihat kasus penembakan pesawat Malaysia Air Lines MH17 di atas wilayah udara Ukraina yang merupakan wilayah kedaulatannya sehingga Ukraina sangat bertanggung jawab atas keselamatan dan keamanan penerbangan di wilayah udaranya, tercipta koordinasi informasi antara Ukraina dengan ICAO (International Civil Aviation Organization) tentang keamanan suatu rute penerbangan.

Keamanan suatu negara yang berdaulat atas wilayah ruang udara diatasnya dalam hal ini Ukraina hanya dapat diketahui oleh negara Ukraina itu sendiri. Berbagai macam konflik seperti konflik militer yang dialami oleh Ukraina seharusnya diinformasikan secara jelas dan rinci terhadap ICAO (International Civil Aviation Organization) agar ICAO (International Civil Aviation Organization) dapat mengantisipasi hal-hal yang tidak perlu dilakukan demi terciptanya keselamatan dan keamanan dalam penerbangan komersial. Ukraina sendiri tidak memberitahukan terkait dengan situasi konflik yang terjadi di negaranya terhadap ICAO (International Civil Aviation Organization), yang mengakibatkan tidak adanya himbauan area rawan konflik yang seharusnya tidak dilalui oleh pesawat sipil dari ICAO (International Civil Aviation Organization) itu sendiri.

ATC (Air Transport Centre) sebagai penyelenggara pelayanan lalu lintas penerbangan bertugas untuk mencegah tabrakan antar pesawat, mencegah tabrakan pesawat dengan penghalang penerbangan, mengatur lalu lintas udara yang aman, cepat dan teratur kepada pesawat terbang, baik yang berada di ground atau yang sedang terbang melintas dengan menggunakan jalur yang telah ditenukan. Dikaitkan dengan tragedi penembakan pesawat Malaysia Air Lines MH17 bahwa tidak adanya perintah larangan melewati rute penerbangan daerah konflik di kota Donetz dari ATC (Air Transport Centre) sehingga pilot memutuskan untuk melewati rute tersebut dan akhirnya terjadi penembakan yang menghancurkan pesawat Malaysia Air Lines MH17 (Prasetyani, 2017:16).

Ukraina sebagai negara yang berdaulat atas wilayah ruang udara yang dilalui oleh pesawat Malaysia Air Lines MH17 merupakan pihak yang bertanggung jawab atas penembakan pesawat Malaysia Air Lines MH17. Seharusnya Ukraina menetapkan zona larangan terbang pada wilayah yang rawan konflik seperti daerah yang dilalui oleh pesawat Malaysia Air Lines MH17 dengan pertimbangan alasan keselamatan penerbangan. Pada Pasal 28 Konvensi Chicago 1944 tentang penerbangan sipil internasional menyatakan bahwa setiap negara bagian yang melakukan kontrak sejauh mungkin dapat dipraktekkan, untuk: 
a. Provide, in its territory, airports, radio services, meteorogical services and other air navigation facilities international air navigation, in accordance with the standards and practices recommended or established from time to time, pursuants to this Convention.

b. Adopt and put into operation the appropriate standard systems of communications procedure, codes, markings, signals, lighting and other operational practices and rules which may be recommended or established from time to time, pursuants to this Convention

c. Collaborate in international measures to secure the publication of aeronautical maps and chart in accordance whit standards which may be recommended or established from time to time, pursuants to this Convention.

Berdasarkan Pasal 28 Konvensi Chicago 1944 tentang penerbangan sipil internasional di atas negara berkewajiban memberikan pelayanan keselamtan penerbangan sipil berupa pelayanan navigasi penerbangan, sehingga Negara Ukraina harus memberikan pelayanan keselamatan dan keamanan atas kedaulatan ruang udara di atas wilayahnya yang dilewati oleh pesawat Malaysia Air Lines MH17. Berdasarkan konsep tanggung jawab negara maka negara Ukraina juga bertanggung jawab untuk memberikan ganti kerugian terhadap maskapai penerbangan dalam hal membantu dalam pencarian jatuhnya maskapai dan segala keperluan yang dibutuhkan dalam melakukan pencarian dan penyelidikan jatuhnya pesawat Malaysia Air Lines MH17.

\section{Simpulan}

Tanggung jawab negara terhadap keselamatan penerbangan bertanggungjawab penuh atas pelayanan semua pesawat yang melintas di atas wilayahnya karena setiap penerbangan membutuhkan panduan dari darat oleh petugas air traffic controller (ATC). Negara yang dilintasi suatu pesawat wajib memberikan layanan panduan penerbangan, tanggung jawab Negara Ukraina terhadap Pe- nembakan Pesawat Malaysia Air Lines MH17 berdasarkan dan Pasal 1 Konvensi Chicago 1944 tentang penerbangan sipil internasional yang mengakui bahwa setiap negara berdaulat mempunyai kedaulaan yang utuh dan penuh atas ruang udara di atas wilayahnya, dan pada Pasal 28 Konvensi Chicago 1944 tentang penerbangan sipil internasional di atas wilayah negara berkewajiban memberikan pelayanan keselamtan penerbangan sipil berupa pelayanan navigasi penerbangan, sehingga Negara Ukraina harus bertanggung jawab untuk memberikan pelayanan keselamatan dan keamanan atas kedaulatan ruang udara di atas wilayahnya yang dilewati oleh pesawat Malaysia Air Lines MH17.

\section{Daftar Pustaka}

Coursehero.com, Padjadjaran University. sesuai Konvensi Chicago 1944 dalam Pasal 1 dinyatakan. Tersedia pada https://www. cousehero.com/ file/ p4km83k/sesuai-Konvensi-Chicago1944-dalam-Pasal-1- dinyatakan- bahwa-setiap-negara/ (diakses pada 15 April 2019).

Huala, Adolf. 1991. Aspek-Aspek Negara dalam hukum Internasional. Jakarta: Rajawali.

Ishaq. 2017. Metode Penelitian Hukum dan Penulisan skripsi, Tesis, Serta Desertasi. Bandung: Alfa Beta.

Istanto, Sugeng. 2010. Hukum Internasional. Yogjakarta:Universitas Atma Jaya.

Kompas.com, kronologi jatuhnya esawat malasyia Air Lines \#MH17 di Ukraina, 2014. Tersedia pada http://internasional.compas.com/read/ 2014/07/18/11141031/Kronologi. Jatuhnya. Pesawat. Malaysia.Airlines. MH17. di.Ukraina (diakses pada 22 April 2019).

Manihuruk, Lumban. 2016. Insiden Pesawat MH17 Ditijau Dari Konvensi Chicago, Jurusan ilmu Hukum, Fakultas Hukum Universitas Tajung Pura.

Martin, Elizabeth. 2002, A Dictionary of Law 5theb. New York: Oxford University Press.

Martono dan Amad Sudiro. 2016. Hukum Udara Nasional Dan Internasional Publik. Jakarta: Rajawali Pers.

Merdeka.com, Panda Surya Wijaya. 2014, Rute penerbangan MH17 sudah disetujui dan aman. Tersedia pada http://www.merdeka.com/dunia/ rute- penerbangan-mh17-sudah-disetujui-danaman.html (diakses 12 April 2019).

Nainggolan, Sudirman H. 2014. Pengaturan Penerbangan Sipil Internasional Menurut Hukum Internasional Yang Melintasi Antar Negara.

Pramono, Agus.2011. Dasar-Dasar Hukum Udara dan RuangAngkasa. Bogor: Ghalia Indonesia,

Prasetyani, Puput Ratih. 2017. Analisis Yuridis Terhadap Tanggung Jawab Negara Ukraina Atas Jatuhnya 
DGS Mangku, IK Radiasta, Tanggung Jawab Negara terhadap Penembakan Pesawat MH17 berdasarkan Hukum...

Pesawat Malaysia Air Lines MH17 Ditinjau Dari Hukum Udara Internasional. Jurusan Ilmu Hukum, Fakultas Hukum Universitas Brawijaya.

Prasetyani, Puput Ratih. 2017. Analisis Yuridis Terhadap Tanggung Jawab Negara Ukraina Atas Jatuhnya Pesawat Malaysia Air Lines MH17 Ditinjau Dari Hukum Udara Internasional. Jurusan Ilmu Hukum, Fakultas Hukum Universitas Brawijaya.

Putri, Adeiana Kartika. 2015. Penembakan Pesawat MH17 Ditinjau dari Hukum Humaniter Internasional. Jurusan Ilmu Hukum, Fakultas Hukum Universitas Airlangga.
Rudy, May. 2011. Hukum Internasional 2. Bandung: PT Refika Aditama.

Sefriani. 2016. Hukum Internasional Suatu Pengantar Edisi Kedua. Jakarta: Rajawali Pers.

Thontowi, Jawahir. 2006. Hukum Internasional Kontemporer. Bandung: PT Refika Aditama.

Wahdah, Nurul. 2015. Tanggung Jawab Ganti Rugi Pada Kecelakaan Pesawat Udara Niaga Menurut Pasal 21 Konvensi Monrealt 1999 (studi kasus Penembakan Pesawat Udara Malasya Air Lines MH17). Jurusan ilmu Hukum, Fakultas Hukum Universitas Tajung Pura. 